\title{
Bioremediation of Industrial Effluent using Cyanobacterial Species: Phormidium mucicola and Anabaena aequalis
}

\author{
Sanjay Kumar Dubey ${ }^{1^{*}}$, Preeti Vyas ${ }^{1}$, Pradeep Tiwari ${ }^{1}$, Amit J. Viswas ${ }^{1}$ \\ and S. P. Bajpai ${ }^{1}$ \\ ${ }^{1}$ Laboratory of Phycology, Department of Botany, Dr. Hari Singh Gour University, Sagar, \\ Madhya Pradesh, India. \\ Authors' contributions
}

This work was carried out in collaboration among all authors. Author SKD designed the study, wrote the protocol and interpreted the data. Author PV anchored the field study, gathered the initial data and performed preliminary data analysis. While authors $P T, A J V$ and SPB managed the literature searches and produced the initial draft. All authors read and approved the final manuscript.

Article Information

DOI: 10.9734/ARRB/2019/v31i130037

Editor(s):

(1) Dr. George Perry, Dean and Professor of Biology, University of Texas at San Antonio, USA

Reviewers:

(1) Yasser El-Nahhal, The Islamic University-Gaza, Palestine. (2) Kannan Pakshirajan, Indian Institute of Technology Guwahati, India. (3) Mustapha Mujeli, Modibbo Adama University of Technology Yola, Nigeria. (4) Abdul Hameed, Govt. IslamiaCollege(Boys), Pakistan (5) Francis Attiogbe, University of Energy and Natural Resources, Ghana. (6) Naz Chaibakhsh, University of Guilan, Iran. Peer review History: http://www.sdiarticle3.com/review-history/11131

Original Research Article

Received 23 June 2014

Accepted 02 September 2014

Published 23 March 2019

\begin{abstract}
Different Industries discharge effluent in different water bodies, which is the only reason of pollution. The main objective of the present study was to investigate the biodegradation and biosorption capacity of some potential cyanobacterial species; Phormidium mucicola and Anabaena aequalis in Textile and Pharmaceutical industries, Mandideep, Bhopal Madhya Pradesh, India. Industrial effluents are contaminated with heavy metal. The effluents were subjected to biological treatment using axenic cyanobacterial strains as batch system for 7 days. Removal efficiencies of the different contaminants were evaluated and compared. Results confirmed the high efficiencies of the investigated species for the removal of the target contaminants which were species and contaminant-dependent. BOD and COD recorded 91.18 and $82.54 \%$ as maximum removal
\end{abstract}


efficiencies achieved by Anabaena aequalis. The highest removal efficiencies of the total suspended solids recorded $53.23 \%$ achieved by Phormidium mucicola, while $41.61 \%$ was recorded as the highest TDS. Concerning the contaminant metals, Phormidium mucicola showed the highest biosorption capacity where 86.12 and $94.63 \%$ removal efficiencies were achieved for $\mathrm{Zn}$ and $\mathrm{Cu}$, respectively. In conclusion, results of the study confirmed the advantageous potential of using the tested cyanobacterial species for the bioremediation of industrial effluent and clearly showed the quality improvement of the discharged effluent which in turn will eliminate or at least minimize the expected deterioration of the receiving environment.

Keywords: Bioremediation; cyanobacterial species; heavy metals; industrial effluent.

\section{INTRODUCTION}

Water covers $71 \%$ of the earth and makes up $65 \%$ of the our bodies. All organisms contain it, live in it, and drink it. Plants and animals require water that is moderately pure and they can not survive if their water is loaded with toxic chemical and harmful microorganisms [1]. Effluents discharge from different sources is directly responsible for water pollution. This is mainly due to continuous discharge of huge quantities of the effluents lead to deterioration in the water quality of the rivers $[2,3,4]$. Any change in $\mathrm{pH}$ of water bodies as a result of influx of effluent; can cause serious change in water chemistry, which can affect resources especially around the river area. These effects on water bodies can be very significant. Besides nutrients, the river water and sediments show terrible levels of organic matter, and heavy metals in worldwide. To overcome water pollution problem some physical and chemical methods are used, but they are expensive and generative concentrated waste that require subsequent treatment and disposal [5]. Traditional methods for the cleanup pollutants usually involve the removal of unwanted materials through sedimentation and filtration, and subsequent chemical treatment such as flocculation, neutralization and electrodialysis before disposal. Biological treatment may provide a suitable means for treatment from waste water [6,7]. Cyanobacterial species characterized by great ability to tolerate such high levels of pollution and proved high efficiency for degrading highly organic contaminants and accumulating heavy metals $[3,8,9]$. Therefore, they could be efficiently used in advanced technologies for bioremediation of the industrial effluents.

Cyanobacteria group is one of the most diverse groups of prokaryotes. They are gram-negative oxygenic photosynthetic bacteria. They can be found in a wide range of water bodies especially where the excess nutrient input of anthropogenic activities. Many species of cyanobacteria have nitrogenase enzyme, they convert atmospheric nitrogen into ammonium. Their photoautotrophic nature and the ability of some species to fix atmospheric nitrogen enable them to be producers, as opposed to consumers, and make their growth and maintenance inexpensive [10], [11]. Metabolic activities are not affected by the decrease in the levels of the biodegradable pollutants that they may break down. Cyanobacteria have been used efficiently as a low-cost method for remediating all industrial effluents as well as transformation and removal of heavy metals $[12,8]$.

Recently, there have been increasing interest about using cyanobacteria as pollution control agents since they possess many advantages over other microorganisms isolated from soil. Remediation capabilities of cyanobacteria toward environmental pollutants can be improved and enhanced through genetic engineering technologies $[13,4,9]$. However, the beneficial application of cyanobacteria in remediation of contaminated waters and industrial effluents is still not optimally manipulated $[14,15]$.

\subsection{Aims and Objectives}

The main objective of the present study was to investigate the remediation capacity of some potential cyanobacterial species isolated from Textile and Pharmaceutical industrial effluent.

\section{MATERIALS AND METHODS}

Survey of different sites of industrial effluent for identification of different algal forms from taxonomic point of view will be undertaken. Samples were collected from two industries (Textile and pharmaceuticals industries, from Mandideep, Bhopal, M.P.), India. Effluents were collected in large sterilized containers and polythene bags respectively. Thus, it is expected that the effluents contain industrial pollutants 
such as heavy metals which are not likely to be removed by that primary treatment of the industries. Grab samples representing all effluents entering the plant during $24 \mathrm{~h}$ were collected from both plants to avoid the fluctuation in the flow and the strength of the effluent.

Physico-chemical characteristics of effluents were carried out by standard methods [16]. Such as biochemical oxygen demand (BOD); chemical oxygen demand (COD); total suspended solids (TSS); total dissolved solids (TDS); and Textile and pharmaceuticals effluents contain high $\mathrm{Zn}$ and $\mathrm{Cu}$ were characterized before and after treatment to determine the effectiveness of the remediation process $[17,18]$. All the investigated parameters were determined using the standard techniques described by [19] in the standard methods for the examination of water and effluent.

Standard microbiological methods were followed for the isolation of cyanobacteria. Algal samples were microscopically examined and the selected cyanobacterial species were grown in Chu No.10 (1942) media was used as culture media. and the $\mathrm{pH}$ was adjusted to 7.2 with $\mathrm{HCl}$. Media has sterilized by autoclaving separately at $121^{\circ} \mathrm{C}$ for $20 \mathrm{~min}$. Micronutrient solution was sterilized by filtration through $0.22 \mathrm{~mm}$ polycarbonate membrane to avoid interaction and precipitation of heavy metals. Chu No.10 media was freshly prepared from $A$ and $B$ where $1.0 \mathrm{ml}$ of each component of solution $A$ and $1.0 \mathrm{ml}$ of Solution $B$ were combined and diluted to $1.0 \mathrm{l}$, sterilized as mentioned and used for selective culturing of the selected species. After inoculation, all the selected species were incubated at room temperature $\left(28^{\circ} \mathrm{C}\right)$ and day light with manual shaking every $24 \mathrm{~h}$ to avoid adhesion of the algae on the walls of the glass vessels until heavy growth appeared within 3 weeks. Identification was confirmed based upon the keys given by several authors $[20,21]$ for microscopic parameters. The isolated cyanobacteria were identified with the help of classical manuals. Two different cyanobacterial species; Anabaena aequalis and Phormidium mucicola; were selected for further study.

\subsection{Axenity and Bioassay}

Unialgal cultures usually remained contaminated with bacteria and therefore to free them from bacteria is a pre requisite for further studies $[22,23,24,25]$. The cultures were made bacteria free by ultraviolet irradiation for varying periods and inoculated in the medium. Axenic cultures were prepared of these isolate species. However, before using these strains in the bioremediation of the contaminated industries effluents, their axenity was checked using agar phototactic response method. Semi solid standard agar medium was prepared and liquated into test tubes and sterilized. Each tube was inoculated with $100 \mu \mathrm{l}$ of cyanobacterial culture (two replicates per culture). Light was prevented to reach the top $10 \mathrm{~cm}$ of the tube using aluminum foil. All the tubes were incubated in optimal conditions $\left(28^{\circ} \mathrm{C}\right)$ in an illuminated incubator. Based on the phototactic response phenomena the cyanobacterial filaments were grown toward light direction through the semi solid agar, but bacteria did not grown. After 7 days incubation of the agar column was dragged out the tube on sterilized Petri dish. The agar column was sliced into ten slices $1 \mathrm{~cm}$ per each. Each slice was stranded longitudinally and transversally cut under common sterilized conditions to separate the algal filaments surrounded with a small piece of agar. Each agar piece involving cyanobacterial growth was inoculated into standard selective liquid medium. After incubation, each inoculated culture was tested for contamination using general bacterial medium (nutrient agar). In bioremediation bioassay, the tested species were checked for their axenity, and the liquid cultures were tested by plating on bacterial nutrient medium and incubating at $28^{\circ} \mathrm{C}$ for 7 days. Only axenic cultures were involved in the assays. The selected species were inoculated individually in $100 \mathrm{ml}$ culturing medium (three replicates) and incubated for 2 weeks till heavy growth was obtained. Effluents from both industries (textile and pharmaceutical) was dispensed $(900 \mathrm{ml}$ each) in 18 sterilized conical flasks, nine flasks for each effluent. Each culture $(100 \mathrm{ml})$ was separately seeded at a final volume of 1 l each (three replicates/strain/effluent) and incubated under the previously mentioned conditions for 7 days. Another six flasks (three flasks for each industry) were supplied by $1 \mathrm{ml}$ each of the effluent of both industries without seeding with cyanobacteria to serve as control for the bioassay (each experiment has been performed in triplicate). They were incubated under the same conditions. For the determination of heavy metals and other parameters residues, samples were collected at $24 \mathrm{~h}$ interval. At each sampling time, $130 \mathrm{ml}$ from each flask were aseptically drawn, where all the investigated parameters were determined and their removal efficiencies using the selected species were determined by 
PERKIN ELMER OPTIMA 5300 DV ICP-OES (Inductively Coupled Plasma Optical Emission Spectrophotometer) method and result were obtained from SAIF (Sophisticated Analytical Instrument Facility) Indian Institute of Technology Madras, Chennai.

\section{RESULTS AND DISCUSSION}

Following species have been collected from pharmaceutical and Textile industries (Table 1).

Phormidium mucicola and Anabaena aequalis investigated as free-living cells for their ability for organic matter biodegradation and heavy metal removal from the effluent. They were selected based on their dominance and survival in the highly polluted water of Pharmaceutical industries and textile industries where they acquired high resistance and acclimatized to deal with high loads of different contaminants. They were also proven high ability for degradation of the heavy metals. Therefore, the selected species were considered promising candidates for biological treatment of the industrial effluents.

\subsection{Industrial Effluent Characteristics}

Effluent produced by the two industries was characterized (Table 2, control). BOD, COD, TSS, TDS, Zn and Cu recorded averages of 140 , $360,167,1150,0.11$ and $0.04 \mathrm{mg} / \mathrm{l}$, respectively, in the effluent of the textile industry. Significantly higher levels for almost all the tested parameters were detected in the pharmaceutical effluent where 198, 445, 387, 1430, 0.01, and $0.03 \mathrm{mg} / \mathrm{l}$ were recorded as average.

However, $\mathrm{Zn}$ recorded much lower average in the pharmaceutical effluent $(0.01 \mathrm{mg} / \mathrm{l})$ compared to that of the textile effluent $(0.11 \mathrm{mg} / \mathrm{l})$ while no significant differences were recorded in the $\mathrm{Cu}$ levels among the two industry (0.04 and 0.03 $\mathrm{mg} / \mathrm{l}$ in the textile and pharmaceutical effluents). Nitrogen and phosphorus content in both effluents $[26,27,28]$ along with the toxic industrial contaminants suppressed the growth of cyanobacteria or any other algae.

Table 1. Occurrence of cyanobacteria in effluents of different sites of Pharmaceutical, Textile industries

\begin{tabular}{|c|c|c|c|c|c|c|}
\hline \multirow[t]{3}{*}{ Cyanobacterial species } & \multicolumn{6}{|c|}{$\begin{array}{r}\text { Industries } \\
\end{array}$} \\
\hline & \multicolumn{3}{|c|}{ Pharmaceutical } & \multicolumn{3}{|c|}{ Textile } \\
\hline & $\begin{array}{l}\text { Site } \\
\text { I }\end{array}$ & $\begin{array}{l}\text { Site } \\
\text { II }\end{array}$ & $\begin{array}{l}\text { Site } \\
\text { III }\end{array}$ & $\begin{array}{l}\text { Site } \\
\text { I }\end{array}$ & $\begin{array}{l}\text { Site } \\
\text { II }\end{array}$ & $\begin{array}{l}\text { Site } \\
\text { III }\end{array}$ \\
\hline Chroococcus disperses & + & + & + & + & + & + \\
\hline Rhabdoderma irregular & - & - & - & - & - & + \\
\hline Aphanocapsa elachista & - & - & - & + & - & - \\
\hline Holopedium irregular & - & - & - & + & - & - \\
\hline Gloeothece linearis & - & - & - & - & - & - \\
\hline Gomphosphaeria aponina var.cordiformis & - & - & - & + & - & - \\
\hline Microcystis aeruginosa & + & + & + & + & + & + \\
\hline Spirulina major & + & + & + & - & - & - \\
\hline Oscillatoria amoena & - & - & - & + & + & + \\
\hline Phormidium inundatum & + & + & + & + & + & + \\
\hline Phormidium mucicola & + & + & + & + & + & + \\
\hline Schizothrix lacustris & + & + & + & - & - & - \\
\hline Schizothrix tinctoria & - & - & - & - & - & - \\
\hline Anabaena aequalis & + & + & + & + & + & + \\
\hline Anabaena affinis & + & & + & & & \\
\hline Nostoc verrucosum & + & + & + & + & + & + \\
\hline Nodularia spumigena & - & - & - & - & - & - \\
\hline Aphanizomenon flos-aquae & + & + & + & + & + & + \\
\hline Cylindrospermum catenatum & - & - & + & - & - & - \\
\hline Scytonema crispum & - & + & - & - & - & - \\
\hline Plectonema wollei & - & - & - & + & + & + \\
\hline Stigonema mesentericum & - & - & + & + & - & - \\
\hline Stigonema ocellatum & + & + & + & + & + & + \\
\hline
\end{tabular}


Table 2. Residue concentrations (RC) of the quality parameters from the contaminated industrial effluents

Textile industry effluent (Before treatment value in $\mathrm{mg} / \mathrm{l}$ )

\begin{tabular}{lllllll}
\hline Time(day) & BOD & COD & TSS & TDS & ZN & CU \\
\hline Raw water & 140 & 360 & 167 & 1,150 & 0.11 & 0.04 \\
2 & 89 & 289 & 132 & 887 & 0.09 & 0.01 \\
3 & 80 & 243 & 100 & 766 & 0.05 & 0.02 \\
4 & 81 & 200 & 101 & 756 & 0.12 & 0.04 \\
5 & 70 & 187 & 98 & 611 & 0.09 & 0.05 \\
6 & 120 & 387 & 154 & 900 & 0.14 & 0.06 \\
7 & 143 & 331 & 143 & 998 & 0.12 & 0.07 \\
\hline
\end{tabular}

Pharmaceutical industry effluent (Before treatment value in $\mathrm{mg} / \mathrm{l}$ )

\begin{tabular}{lllllll}
\hline Time(day) & BOD & COD & TSS & TDS & ZN & CU \\
\hline Raw water & 198 & 445 & 387 & 1430 & 0.01 & 0.03 \\
2 & 187 & 465 & 411 & 1457 & 0.04 & 0.01 \\
3 & 199 & 412 & 376 & 1432 & 0.03 & 0.04 \\
4 & 176 & 398 & 311 & 1200 & 0.01 & 0.04 \\
5 & 166 & 345 & 298 & 1100 & 0.03 & 0.06 \\
6 & 178 & 411 & 321 & 1289 & 0.05 & 0.02 \\
7 & 200 & 378 & 365 & 1008 & 0.02 & 0.01 \\
\hline
\end{tabular}

Table 3. Residue concentrations (RC) of the quality parameters from the contaminated industrial effluents using the selected cyanobacteria at different exposure time ICPOES

Textile industries effluent (After treatment value in $\mathrm{mg} / \mathrm{l}$ )

\begin{tabular}{lllllllllllll}
\hline \multicolumn{4}{c}{ Anabaena aequalis } & \multicolumn{8}{c}{ Phormidium mucicola } \\
\hline Days & BOD & COD & TSS & TDS & ZN & CU & BOD & COD & TSS & TDS & ZN & CU \\
\hline Raw water & 149 & 312 & 200 & 1012 & 0.11 & 0.05 & 148 & 324 & 234 & 1134 & 0.12 & 0.07 \\
2 & 141 & 301 & 199 & 1011 & 0.09 & 0.05 & 143 & 321 & 223 & 1124 & 0.10 & 0.07 \\
3 & 132 & 298 & 189 & 1001 & 0.06 & 0.03 & 132 & 309 & 212 & 1120 & 0.5 & 0.05 \\
4 & 121 & 288 & 170 & 998 & 0.05 & 0.02 & 122 & 289 & 206 & 1103 & 0.5 & 0.03 \\
5 & 100 & 198 & 150 & 988 & 0.03 & 0.02 & 101 & 281 & 189 & 1087 & 0.3 & 0.02 \\
6 & 76 & 122 & 132 & 986 & 0.03 & 0.02 & 98 & 256 & 167 & 1079 & 0.1 & 0.1 \\
7 & 62 & 98 & 112 & 983 & 0.02 & 0.01 & 78 & 249 & 156 & 1012 & 0.1 & 0.1 \\
\hline
\end{tabular}

Pharmaceutical industries effluent (After treatment value in $\mathrm{mg} / \mathrm{l}$ )

\begin{tabular}{lllllllllllll}
\hline & \multicolumn{4}{c}{ Anabaena aequalis } & \multicolumn{8}{c}{ Phormidium mucicola } \\
\hline Days & BOD & COD & TSS & TDS & ZN & CU & BOD & COD & TSS & TDS & ZN & CU \\
\hline Raw water & 254 & 432 & 321 & 1349 & 0.08 & 0.07 & 231 & 421 & 401 & 1401 & 0.06 & 0.07 \\
2 & 233 & 428 & 311 & 1323 & 0.06 & 0.05 & 211 & 421 & 387 & 1400 & 0.04 & 0.06 \\
3 & 212 & 412 & 306 & 1321 & 0.06 & 0.04 & 201 & 401 & 381 & 1387 & 0.04 & 0.04 \\
4 & 198 & 398 & 285 & 1287 & 0.04 & 0.04 & 192 & 356 & 372 & 1345 & 0.02 & 0.03 \\
5 & 167 & 378 & 265 & 1287 & 0.03 & 0.02 & 187 & 241 & 324 & 1302 & 0.01 & 0.03 \\
6 & 121 & 321 & 209 & 1270 & 0.02 & 0.01 & 123 & 209 & 283 & 1265 & 0.01 & 0.01 \\
7 & 98 & 243 & 187 & 1201 & 0.02 & 0.00 & 98 & 198 & 223 & 1230 & 0.00 & 0.01 \\
\hline
\end{tabular}

\subsection{Treatability and Removal Efficiency of Effluent}

\subsubsection{Contaminants}

Residue levels of the selected quality parameters were determined (Tables 2 and 3 ) and the removal efficiencies (RE \%) as results of the biological treatment using the selected species were calculated. As a general trend, the two tested species exhibited positive correlation between their RE\% of all the tested parameters and the exposure time up to the last exposure day for both types of effluents.

\subsubsection{Organic matter removal}

Biochemical oxygen demand Removal of BOD from industrial effluents of both industries using the selected algae revealed the following points: 
1. High REs\% were obtained for BOD removal from industrial effluent by the selected species with Anabaena aequalis $(90.65 \%)$ and finally Phormidium mucicola $(81.9 \%)$.

2. Despite the RE variations of BOD achieved by the tested species, RC(s) of the BOD in the industrial effluent reached acceptable limits $(19,20$ and $32 \mathrm{mg} / \mathrm{l}$ by Anabaena aequalis and Phormidium mucicola, respectively) after 7 days exposure which is much lower than the maximum permissible limit [29] of $60 \mathrm{mg} / \mathrm{l}$ stated by the Environmental Laws for safe discharge into surface water courses. When these figures compared with those obtained by the control it was showed that the natural microbial population of the effluent achieved a maximum removal of $50 \%$ after 5 days equivalent to $60.7 \mathrm{mg} / \mathrm{l}$ (MPL of the BOD) after which there was a sharp decline in the efficiency associated by increasing the $\mathrm{RC}$ reaching $140 \mathrm{mg} / \mathrm{l}$ and $3.20 \%$ RE after 7 exposure of days.

3. Comparing BOD removal by the selected cyanobacteria revealed very high efficiency for all of them in the degradation of biodegradable organic matter which is stimulated by increasing the levels of the pollutant in the wastewater.

Chemical oxygen demand Removal of COD from the industrial effluents using the selected species revealed the following points:

1. Anabaena aequalis considered the most effective for removing COD from the industrial effluent achieving the maximum $\mathrm{RE}$ of $83.68 \%$ compared to the RE achieved by Phormidium mucicola (45.00\%) after 7 exposure days. However, Phormidium mucicola exhibited higher COD RE \% within the first $24 \mathrm{~h}$ compared to Anabaena aequalis.

2. The lowest residue concentration of 100 $\mathrm{mg} / \mathrm{l}$ was achieved by Anabaena aequalis which is the maximum acceptable limit stated by the law (MPL for COD $=100$ $\mathrm{mg} / \mathrm{l}$ ) while Phormidium mucicola could not bring the COD levels of the effluent to better quality. They recorded 180 and 246 $\mathrm{mg} / \mathrm{l}$, respectively, and required longer exposures. The highest RE\% achieved by the control culture recorded $50.11 \%$ (170.59 $\mathrm{mg} / \mathrm{l})$ after 5 exposure days.

3. Similar to BOD removal, the natural microorganisms in the control culture were inhibited by the high Strength of the industrial effluent leading to reduction in the COD removal.

4. Although high REs\% of the COD was achieved by the selected species, none of them could bring the COD levels in the effluent below the MPL during the investigated exposure time (1 week). This may be attributed to the need for longer time for achieving the proper quality. It could also result from the inhibition in cyanobacterial growth due to the higher COD levels in the pharmaceutical effluent compared to that of the textile effluent.

\subsubsection{Solids removal}

Total suspended solids (TSS) Removal of TSS from the industrial effluents using the selected species revealed the following points:

1. The highest recorded TSS REs\% in the effluent recorded 42.0 and $29.12 \%$ achieved by Anabaena aequalis, and Phormidium mucicola (125 and $133 \mathrm{mg} / \mathrm{l}$ $\mathrm{RC})$, respectively, after 7 days.

2. According to the law, $60 \mathrm{mg} / \mathrm{l}$ is stated as the MPL of the TSS; therefore none of the tested species reached the required efficiency to bring the TSS in the effluents below the MPL during the tested exposure time. This indicates that they required longer time, heavier biomass or different application using the same species to achieve that quality.

3. In contrast to cyanobateria control culture achieved higher TSS removal form the textile effluent compared to that of the pharmaceutical effluent.

Total dissolved solids (TDS) Removal of TDS from the industrial effluent using the selected species revealed the following points:

1. The maximum TDS REs\% obtained for the effluent by the tested species ranged between a maximum of $16.66 \% \quad(1,078$ $\mathrm{mg} / \mathrm{l})$ achieved by Phormidium mucicola and a minimum of $12.00 \%(1,119 \mathrm{mg} / \mathrm{l})$ obtained by Anabaena aequalis after 7 exposure days. Phormidium mucicola exhibited higher TDS RE\% at the shorter exposures (up to 2nd day) compared to Anabaena aequalis.

2. Similar behavior for TSS removal was shown by bacteria of the control culture where higher TDS removal was achieved 
form the textile effluent compared to that of the pharmaceutical effluent.

3. Since the TDS content in the effluents were lower than the MPL of the TDS $(2,000 \mathrm{mg} / \mathrm{l})$, the residual concentrations of the TDS produced in the final effluents by all the tested species as well as the two controls improved and still within the safe range for discharging.

\subsubsection{Heavy metals removal}

Results revealed the following points:

1. Phormidium mucicola recorded the highest REs\% for Zn from EWTP (86.12) and Anabaena aequalis $(70.88 \%)$ recording RCs of 0.0247 , and $0.0370 \mathrm{mg} / \mathrm{l}$ by three species, respectively, after 7 days.

2. Although low $\mathrm{Zn}$ levels were detected in the pharmaceutical effluent, lower Zn REs were achieved compared to those obtained for the textile effluent. $\mathrm{Zn}$ removal recorded 78.2 , and $65.00 \%$ achieved as the highest Zn REs\% by Phormidium mucicola, and Anabaena aequalis, respectively $(0.0123$, and $0.0182 \mathrm{mg} / \mathrm{l}$, respectively) after 7 days.

3. Although all the average levels of $\mathrm{Zn}$ for both effluents were below the MPL of 5 $\mathrm{mg} / \mathrm{l}$ before the treatment, $\mathrm{Zn}$ levels were reduced producing much better effluent quality. Zinc removal was stimulated by increasing its level in the wastewater.

4. Concerning $\mathrm{Cu}$, much higher REs\% were recorded for effluent compared to those obtained for $\mathrm{Zn}$ removal regardless it's high toxicity. This may be attributed to the high resistance of the selected members which was stimulated by increasing $\mathrm{Cu}$ levels in the wastewater. 94.63, 90.99 and $90.64 \% \mathrm{RE}$ of $\mathrm{Cu}$ were achieved by Phormidium mucicola, and Anabaena aequalis $(0.0031$, and $0.0054 \mathrm{mg} / \mathrm{l} \mathrm{RC})$, respectively, after 7 days.

\section{CONCLUSION}

In conclusion, results confirmed that Phormidium mucicola and Anabaena aequalis are the effective species for BOD, COD, TSS, TDS, Zn and $\mathrm{Cu}$ removal from the effluents of the textile and pharmaceutical industries. $\mathrm{Zn}$ and $\mathrm{Cu}$ both are toxic heavy metals. Effluents discharge in water bodies can affect the living organism. These cyanobacterial species are able to remove these metals from water body. Absorption of metals increase in the higher concentration.
Presence of these cyanobacteria can low BOD, COD, TSS, TDS.

\section{COMPETING INTERESTS}

Authors have declared that no competing interests exist.

\section{REFERENCES}

1. Denwar CO. Encarta encyclopedia ground water and surface water: A single resource; 2009.

(Accessed 15 April 2014)

Available:http://www.ars.usda.gov/sp2usar files/program $/ 301 \%$

2. El-Bestawy E. Studies on the occurrence and distribution of pollutant metals in freshwater phytoplankton and bacteria in Lake Mariut, Alexandria, Egypt. Ph.D. Thesis, Department of Environmental Biology, Faculty of Sciences, Manchester University, Manchester; 1993.

3. El-Bestawy E, Abd El-Salam AZ, Abd ElRahman HM. Potential use of environmental cyanobacterial species in bioremediation of Lindane-contaminated effluents. Int Biodeterior. Biodegradation. 2007;59(3):180-192.

4. Mansy AH, El-Bestawy E. Toxicity and biodegradation of fluometuron by selected members of cyanobacteria. World $\mathrm{J}$ Microbiol Biotechnol. 2002;18:125-131.

5. Komori K, Rivas A, Toda K, Ohtake H. Biological removal of toxic chromium using an Enterobacter cloacae strain that reduces chromate under anaerobic conditions. Biotechnol. Bioeng. 1990;35:951-954.

6. Lovley DR, Coates JD. Bioremediation of metal contamination. Curr Opin Biotechnol. 1997;8:285-289.

7. Rittmann BE, Nerenberg R, Lee KC, Najm I, Gillogy TE, Ehman GE, Adham SS. Hydrogen based hallow- fiber membrane biofilm reactor (MBFR) for removing oxidized contaminants. Water Supply. 2004;4(1):127-133.

8. Podda F, Zuddas P, Minacci A, Pepi M, Baldi F. Heavy metal coprecipitation with hydrozincite $\left[\mathrm{Zn} 5(\mathrm{CO} 3) 2(\mathrm{OH})^{6}\right]$ from mine waters caused by photosynthetic microorganisms. Appl Environ Microbiol. 2000;66(11):5092-5098.

9. Palmer $\mathrm{CM}$. Algae and water pollution. Castelhouse Publications Ltd. USA; 1980. 
10. Castenholz RW, Waterbury JM. Oxygenic photosynthetic bacteria. Group I. Cyanobacteria. In: Hensyl WR (ed) Bergy's Manual of Systematic Bacteriology. Williams and Wilkins: Baltimore. 1989; 1710-1727.

11. Somashekar RK, Ramaswamy SN. Algal indicators of paper mill wastewater. Phykos. 1983;22:161-166.

12. Lefebvre DD, Kelly D, Budd K. Biotransformation of $\mathrm{Hg}$ (II) by cyanobacteria. Appl Environ Microbiol. 2007;73(1):243-249.

DOI: 10.1128/AEM.01794-06.

13. Kuritz T, Wolk CP. Use of filamentous cyanobacteria for biodegradation of organic pollutants. Appl Environ Microbiol. 1995;61:234-238.

14. Jeganathan K. Bioremediation studies on oil refinery industry effluent using Oscillatoria earli Gartner, M.Phil. Dissertation, Bharathidasan University: Tiruchirapalli; 2006.

15. Kannan S. Biodiversity of cyanobacteria in freshwater ponds of Poondi. Thanjavur. M.Phil, Dissertation, Bharathidasan University. Tiruchirapalli; 2006.

16. APHA. Standard methods for the examination of water and waste water. $19^{\text {th }}$ Ed. American Public Health Association: Washington DC; 1995.

17. Boominathan M. Bioremediation studies on dairy effluent using cyanobacteria. Ph.D. Thesis. Bharathidasan University. Tiruchirapalli Tamil- Nadu. India; 2005.

18. Cairns J Jr, Dickson KL. Asimple method for the biological assessment of the effects of waste discharge on aquatic bottom dwelling organisms. J. Wat. Poll. Control Fed. 1971;43:722-725.

19. Celesseri LS, Greenberg CG, Eaton AD. Standard method for the examination of water and wastewater, $20^{\text {th }} \mathrm{Ed}$. American Public Health Association (APHA): USA; 1999. ISBN: 0875532357.
20. Geitler L. Cyanophaceae. In: Rabenhorst's Kryptogamen flora. Akademische verlags gesellschaft lepzig. 1932;1196. French

21. Desikachary TV. Cyanophyta, Indian Council of Agricultural Research: New Delhi; 1959.

22. Ash N, Jenkins M. Biodiversity and poverty reduction: The importance of biodiversity for ecosystem services. Final report prepared by the United Nations Environment Programme World Conservation Monitoring Centre (UNEPWCMC) for the Department for International Development (DFID); 2006.

23. Anagnostidis $\mathrm{K}$, Komárek J. Modern approaches to the classification system of cyanophytes. É. Introduction. Arch. Hydrobiol. Suppl. 1985;71:91-302.

24. El-Nahhal $Y$, Awad $Y$, Safi J. Bioremediation of acetochlor in soil and water systems by cyanobacterial mat. International Journal of Geosciences. 2013;4:880-890.

25. Safi J, Awad $Y$, El-Nahhal $Y$. Bioremediation of diuron in soil environment: Influence of cyanobacterial mat. American Journal of Plant Sciences. 2014;5:1081-1089.

26. El-Bestawy E, Hussein $\mathrm{H}$, Baghdadi $\mathrm{H}$, ElSaka M. Comparison between biological and chemical treatment of wastewater containing nitrogen and phosphorus. J Ind Microbiol Biotechnol. 2005;32:195-203.

27. Ezeronye OU, Ubalua AO. Studies on the effect of abattoir and industrial effluent on the heavy metal and microbial quality of Abariver in Abia state of Nigeria. Afr. J. Biotechnol. 2005;4(3):266-272.

28. Ellis BE. Degradation of phenolic compounds by freshwater algae. Plant Sci Lett. 1977;8:213-216.

29. American Public Health Association; APHA. Standard methods for the examination of water and waste water; 1998.

(c) 2019 Dubey et al.; This is an Open Access article distributed under the terms of the Creative Commons Attribution License (http://creativecommons.org/licenses/by/4.0), which permits unrestricted use, distribution, and reproduction in any medium, provided the original work is properly cited.

Peer-review history:

The peer review history for this paper can be accessed here: http://www.sdiarticle3.com/review-history/11131 